\title{
Analisa Perbandingan Kinerja Algoritma Kolaboratif Filtering
}

\author{
Rosalina*, Hokki Putra Andika \\ Information Technology Study Program, President University \\ *Corresponding author: rosalinalpresident.ac.id
}

\begin{abstract}
Abstrak - Transportation Management System is very needed in optimize efficiency and effectiveness on logistics company. One of the most important part of transportation management system is determining delivery route from a depot to each customer. A lot of studies have been done about determining the best route in a shipping ritation with various algorithms. In the previous research, determination of delivery route is done without any implementation in the application. During the route determination is still done manually it will make a flow process in the company is not maximize. Model development aims to make an implementation application that serves to determine delivery route based on the problem of vehicle routing problem using the nearest neighbour method which is restricted to heavy loads in the transportation. Implementation of route determination an application will be done based on business process in transportation company, named PT. $X$, so it is necessary to observe the company. Compared to previous research, this research will determine delivery route in application based on the problem of vehicle routing problem using the nearest neighbour method.
\end{abstract}

\section{PENDAHULUAN}

Pertumbuhan Internet menyebabkan ledakan ecommerce dan lingkungan online, hal ini membuat pengguna dibanjiri oleh pilihan yang harus diambil dan mungkin tidak memiliki waktu atau pengetahuan untuk mengevaluasi pilihan tersebut. Sistem recommender telah terbukti menjadi salah satu cara untuk online user dalam mengatasi masalah ini.

Sistem recommender mencoba untuk membuat profile pilihan pengguna per-item, dan membuat model hubungan antara pengguna dan item. Tugas dari sistem recommender adalah untuk merekomendasikan item yang sesuai dengan selera pengguna untuk memudahkan pengguna dalam memilih atau membeli item yang jumlahnya sangat berlimpah. Collaborative filtering merupakan teknik yang paling umum digunakan dalam memprediksi informasi yang melibatkan kolaborasi antara beberapa pengguna dimana tersedia informasi history dari pengguna [7].
Collaborative filtering memiliki tugas merekomendasikan item kepada pengguna. Korelasi antara rating dari beberapa pengguna dengan rating pada item digunakan untuk menghitung prediksi rating. Sebagai contoh, sebuah web film akan menawarkan pengguna untuk memberikan rating film disitusnya, kemudian situs tersebut menawarkan film-film yang memiliki rating tertinggi kepada penggunanya.

Untuk memprediksi rating, rating dihitung berdasarkan item-item yang memiliki kesamaan dengan item yang dipertanyakan dan telah memiliki rating yang sebelumnya telah diberikan oleh pengguna. Teknik ini disebut dengan item-based collaboratif filtering. Sedangkan teknik lain yang disebut dengan user-based collaboratif filtering menghitung kesamaan antara pengguna untuk mencari pengguna yang paling mirip dan memberikan sebuah rating berdasarkan tingkat kemiripannya.

\section{Permasalahan}

Semakin berkembangnya algoritma dalam collaboratif filtering dan metode penghitungan korelasi, muncul masalah baru, yaitu bagaimana menemukan kombinasi terbaik antara algoritma dalam collaboratif filtering dengan metode penghitungn korelasi. Penggunaan metode penghitungan korelasi yang kurang pas bisa menyebabkan performa dari metode collaboratif filtering menurun, sehingga tingkat akurasi yang dihasilkan rendah. Sehingga bisa ditarik kesimpulan bahwa menemukan metode penghitungan korelasi yang terbaik untuk digabungkan dengan metode collaboratif filtering sangat dibutuhkan untuk nantinya dapat menghasilkan metode dengan tingkat akurasi yang tinggi.

\section{Tujuan}




\section{IT FOR SOCIETY, Vol. 03, No. 01 \\ ISSN 2503-2224}

Penelitian yang dilakukan adalah membandingkan algoritma dalam collaboratif filtering dengan metode penghitungan korelasi yang ada dengan menggunakan dataset yang sama untuk setiap skenario percobaan. Dari percobaan yang dilakukan dengan menggabungkan setiap algoritma dalam collaboratif filtering dengan metode penghitungan korelasi akan didapatkan kesimpulan metode penghitungan korelasi yang mana yang paling cocok dengan algoritma collaboratif filtering tertentu.

Manfaat penelitian ini adalah:

1. Memberikan gambaran dari performa untuk setiap metode penghitungan korelasi

2. Memberikan informasi akurasi dan performa untuk setiap metode collaboratif filtering yang diuji

3. Memberi rekomendasi penggunaan metode penghitungan korelasi yang cocok untuk digabungkan dengan metode collaboratif filtering tertentu.

\section{METODOLOGI PENELITIAN}

Dalam penelitian ini tahapan-tahapan dalam proses prediksi rating meliputi:

1. Pengukuran similaritas

Pengukuran similaritas menghitung kemiripan antara dua "baris" atau "kolom" data dari matriks rating. Pengukuran similaritas dalam penelitian ini menggunakan metode cosine similarity dan pearson correlation.

2. Memilih nearest neighborhood

Hasil perhitungan kemiripan antar user dengan menggunakan cosine similarity

3. Prediksi item

Prediksi rating untuk item yang diberikan oleh user

Dalam penelitian ini dataset yang digunakan adalah dataset film dan buku. Dataset film didapatkan dari MovieLens terdiri dari rating 5 bintang, berisi 100234 rating, 2213 aplikasi tag dari 8927 film, beberapa isi dari dataset terlihat pada Gambar 2.1.

\begin{tabular}{|c|c|c|c|c|c|}
\hline ExampleS & $t$ (100234 ex & nples, 0 speci & al attributes, & regular attributes) & View Filter (100234 / 100234): \\
\hline Row No. & userld & movield & rating & timestamp & \\
\hline 1 & 1 & 1 & 5 & 847117005 & \\
\hline 2 & 1 & 2 & 3 & 847642142 & \\
\hline 3 & 1 & 10 & 3 & 847641896 & \\
\hline 4 & 1 & 32 & 4 & 847642008 & \\
\hline 5 & 1 & 34 & 4 & 847641956 & \\
\hline 6 & 1 & 47 & 3 & 847641956 & \\
\hline 7 & 1 & 50 & 4 & 847642073 & \\
\hline 8 & 1 & 62 & 4 & 847642105 & \\
\hline 9 & 1 & 150 & 4 & 847116751 & \\
\hline 10 & 1 & 153 & 3 & 847116787 & \\
\hline 11 & 1 & 160 & 3 & 847642008 & \\
\hline 12 & 1 & 161 & 4 & 847641896 & \\
\hline 13 & 1 & 165 & 4 & 847116787 & \\
\hline 14 & 1 & 185 & 3 & 847641919 & \\
\hline 15 & 1 & 208 & 3 & 847641919 & \\
\hline
\end{tabular}

Gambar 2. 1 Sample Dataset Film

Dataset film dibuat oleh 718 user antara bulan Maret 1996 dan Agustus 2015. User dipilih secara acak dan user yang terpilih telah memberikan rating paling sedikit untuk 20 film [9].

Sedangkan dataset kedua yang dipergunakan dalam penelitian ini adalah dataset buku yang terdiri dari 1,149,780 rating, 271,379 buku dari 278,858 user [10]. Rating yang ada di dataset buku merupakan rating dengan skala 10 , seperti yang terlihat pada Gambar 2.2.

\begin{tabular}{|c|c|c|c|c|}
\hline Examples & $(1149751 \mathrm{ex}$ & imples, 0 specia & ttributes, 3 regular attributes) & lew Filter (1149751 / 1149751): \\
\hline Row No. & User-ID & ISBN & Book-Rating & \\
\hline 1 & 276725 & $034545104 X$ & 0 & \\
\hline 2 & 276726 & 0155061224 & 5 & \\
\hline 3 & 276727 & 0446520802 & 0 & \\
\hline 4 & 276729 & $052165615 X$ & 3 & \\
\hline 5 & 276729 & 0521795028 & 6 & \\
\hline 6 & 276733 & 2080674722 & 0 & \\
\hline 7 & 276736 & 3257224281 & 8 & \\
\hline 8 & 276737 & 0600570967 & 6 & \\
\hline 9 & 276744 & $038550120 \mathrm{X}$ & 7 & \\
\hline 10 & 276745 & 342310538 & 10 & \\
\hline 11 & 276746 & 0425115801 & 0 & \\
\hline 12 & 276746 & 0449006522 & 0 & \\
\hline 13 & 276746 & 0553561618 & 0 & \\
\hline 14 & 276746 & $055356451 X$ & 0 & \\
\hline
\end{tabular}

Gambar 2. 2 Sampe Dataset Buku

Dalam penelitian ini dipilih dari dataset film sebanyak 1659 data dimana penggunanya memberikan rating lebih dari 20 film. Sedangkan dari dataset buku dipilih data sebanyak 1659 .

\section{RESULT}

Penelitian yang dilakukan menghasilkan tingkat performance yang berbeda untuk setiap skenario ketika diuji menggunakan metode collaboratif 
filtering yang berbeda pada metode korelasi yang dipilih. Untuk mengukur tingkat efektifitas dari masing masing skenario percobaan, dilakukan pengukuran dengan menggunakan MAE, RMSE, dan NMAE.

\section{A. Pengujian Terhadap Efek Dari Metode Similarity}

Pada penelitian ini dilakukan pengujian terhadap cosine similarity dan pearson correlation dengan diukur dengan menggunakan Mean Absolut Error (MAE), RMSE dan NMAE untuk mengetahui efek dari metode similarity yang digunakan baik dengan menggunakan dataset film maupun dataset buku.

Gambar 3.1 menunjukkan dengan menggunakan dataset film didapatkan nilai error pada item-based dengan menggunakan pearson correlation lebih rendah dibandingkan pada user-based.

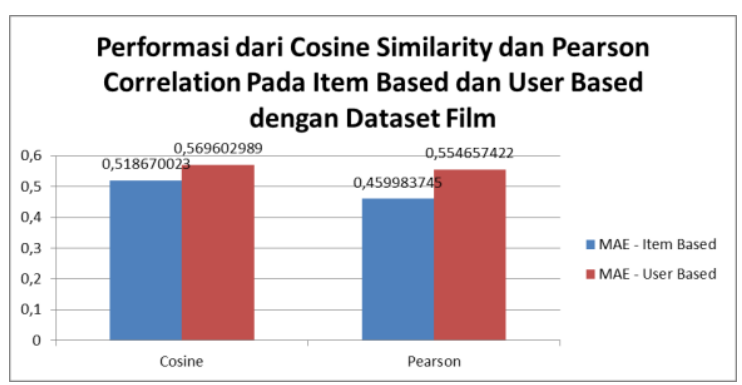

Gambar 3. 1 Performansi metode similaritas pada item-based dan user-based

Gambar 3.2 menunjukkan hasil dari pengukuran dengan menggunakan RMSE. Pada gambar tersebut terlihat bahwa pada item-based, pearson correlation memiliki nilai error 0,60062209 dimana nilai tersebut lebih rendah dibandingkan dengan item-based dengan mengggunakan metode kesamaan cosine similarity. Hal yang sama terjadi pada user-based, dimana bila menggunakan metode pearson correlation nilai error yang dimiliki oleh user-based lebih rendah bila dibandingkan dengan menggunakan metode cosine similarity.

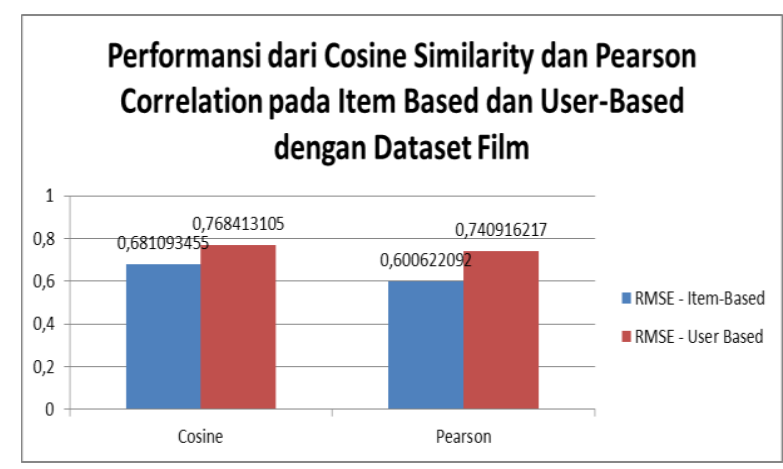

Gambar 3. 2 Performansi metode similarity pada item-based dan user-based

Gambar 3.3 menunjukkan hasil pengukuran dengan menggunakn NMAE, pada gambar terlihat bahwa item-based menggunakan metode pearson memiliki nilai error sebesar 0,114995936 namun bila menggunakan metode cosine similarity memiliki nilai error sebesar 0,129667506. Sedangkan untuk user-based yang menggunakan metode pearson correlation memiliki nilai error sebesar 0,138664356 dan bila user-based menggunakan metode cosine similarity memiliki error sebesar 0,142400747.

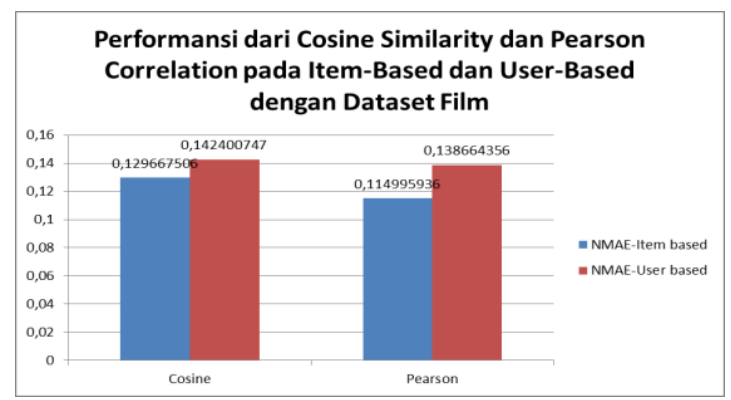

Gambar 3. 3 Performansi metode similarity pada item-based dan user-based

Pengujian dilakukan pula dengan dataset buku, dengan menggunakan pengukuran MAE, RMSE dan NMAE didapatkan hasil seperti yang terlihat pada Gambar 3.4, Gambar 3.5 dan Gambar 3.6.

Pada Gambar 3.4 terlihat bahwa pada item-based yang menggunakan metode pearson correlation memiliki nilai error sebesar 2,4697175 sedangkan bila menggunakan metode cosine similarity memiliki nilai error sebesar 2,543884. Pada Gambar 4.4 juga terlihat untuk user-based yang menggunakan metode pearson correlation memiliki nilai error sebesar 2,4675165 sedangkan bila menggunakan metode cosine similarity memiliki nilai error sebesar 2,492325.

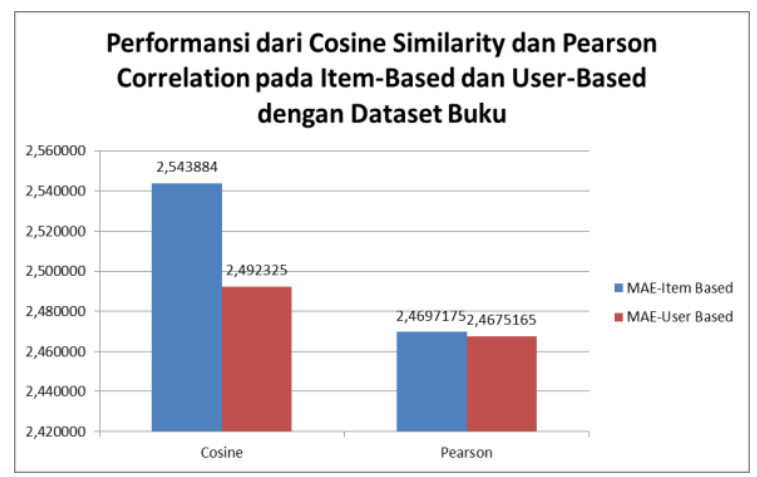

Gambar 3. 4 Performansi Metode Similarity pada Item-Based dan User-Based dengan Dataset Buku 
Namun bila diukur dengan menggunakan RSME item-based yang menggunakan metode pearson correlation memiliki nilai error sebesar 2,82911 dan sedangkan item-based yang menggunakan metode cosine similarity memiliki error sebesar 2,99642. Pada user-based yang menggunakan metode pearson correlation memiliki nilai error sebesar 2,82586 dan bila menggunakan metode cosine similarity memiliki nilai error sebesar 2,86778 seperti yang terlihat pada Gambar 3.5.

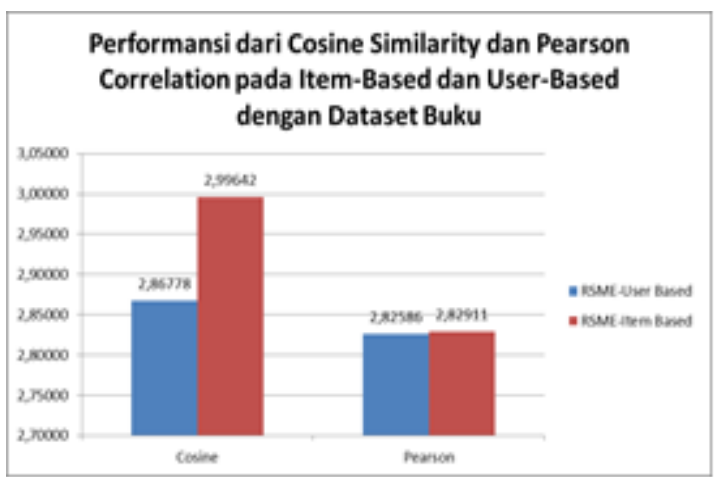

Gambar 3. 5 Performansi Metode Similarity pada Item-Based dan User-Based dengan Dataset Buku

Sedangkan pada Gambar 3.6 terlihat bahwa bila diukur dengan menggunakan NMAE pada itembased dengan menggunakan metode cosine similarity memiliki nilai error yang lebih kecil dibandingkan dengan menggunakan metode pearson correlation, dimana nilai error dengan menggunakan cosine similarity adalah 0,63597105 dan dengan menggunakan metode cosine similarity nilai errornya adalah sebesar 0,617429369.

Sedangkan pada Gambar 3.6 terlihat user-based yang menggunakan metode pearson memiliki nilai error sebesar 0,616879126 sedangkan bila menggunakan metode cosine similarity memiliki nilai error sebesar 0,623081149.

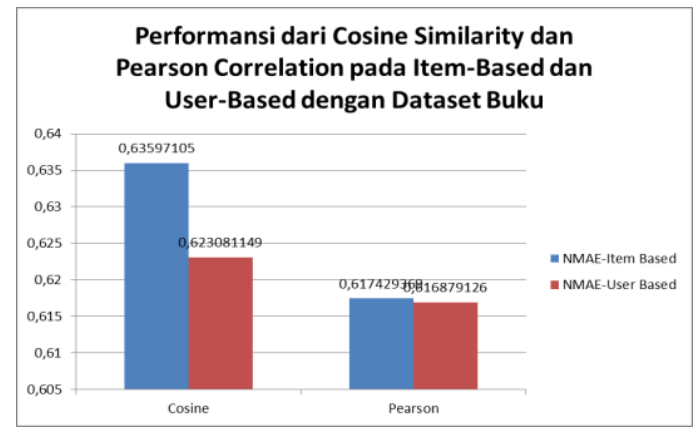

Gambar 3. 6 Performansi Metode Similarity pada Item-Based dan User-Based dengan Dataet Buku

\section{B. Pengujian Terhadap Ukuran Neighborhood}

Jumlah neighborhood memiliki dampak yang signifikan terhadap kualitas prediksi. Jumlah neighborhood digunakan untuk menentukan berapa jumlah user yang memiliki similarity paling tinggi terhadap user tertentu lainnya. Pada penelitian ini dilakukan pengujian dengan nilai $K=10$ sampai dengan nilai $\mathrm{K}=100$.

Pengujian yang pertama dilakukan pada itembased dengan menggunakan metode cosine similarity dengan dataset film dengan menggunakan pengukuran RMSE pada Gambar 4.7 terlihat bahwa pada saat $\mathrm{K}$ dinaikkan dari 10 ke 20 terjadi penurunan nilai sebesar $0,24 \%$ kemudian jika dinaikan lagi ke $\mathrm{K}=30$ nilai error dari menurun sebesar $0,22 \%$, dan pada saat $\mathrm{K}$ dinaikan ke 40 nilai error turun sebesar $0,05 \%$, dan setelah dinaikan ke $K=50$ sampai dengan $K=100$ nilai error menurun dan cenderung datar dengan rata-rata penurunan sebesar $1,61 \%$.

Pada Gambar 3.7 terlihat pula dengan pengukuran menggunakan MAE pada saat $\mathrm{K}$ dinaikan dari $\mathrm{K}=10$ ke $\mathrm{K}=20$ terjadi kenaikan nilai error sebesar $0,71 \%$ dan pada saat nilai $\mathrm{K}$ dinaikan dari 10 ke 40 terjadi kenaikan error sebesar $0,91 \%$, kemudian setelah itu nilai error cenderung turun mulai dari $K=40$ ke $K=100$ dengan nilai rata-rata error turun sebesar 3,04\%. Pada Gambar 4.7 terlihat bahwa dengan menggunakan pengukuran NMAE nilai error meningkat pada saat $\mathrm{K}$ dinaikan dari 10 ke 40 dengan rata-rata kenaikan nilai error sebesar $0,22 \%$, namun setelah itu nilai error menurun perlahan mulai dari $\mathrm{K}=50$ sampai dengan $\mathrm{K}=100$ dengan rata-rata nilai penurunan error sebesar $0,76 \%$.

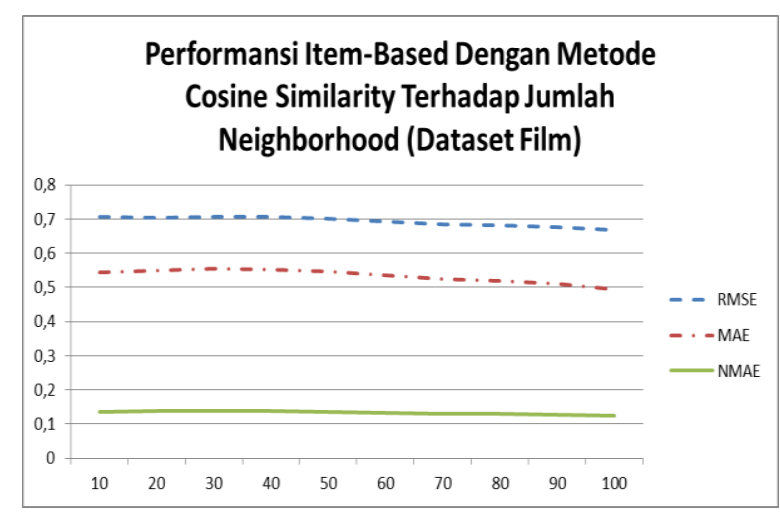

Gambar 3. 7 Performansi Item-Based Dengan Metode Cosine Similarity Terhadap Neighborhood

Kemudian pengujian yang kedua dilakukan pada item-based dengan menggunakan metode pearson correlation, seperti yang terlihat pada Gambar 4.8 dengan menggunakan pengukuran RMSE nilai error cenderung datar namun terlihat niai error 
meningkat pada saat $\mathrm{K}$ dinaikan menjadi 40 dan setelah itu nilai error turun kembali dengan ratarata penurunan nilai error sebesar $0,15 \%$. Pada pengujian dengan menggunakan pengukuran MAE pada saat $\mathrm{K}$ dinaikan menjadi 40 dan 50 nilai error meningkat sebesar $0,20 \%$ dan $0,22 \%$ setelah itu kembali menurun datar dengan rata-rata nilai penurunan error sangat kecil yaitu 0,002\%. Sedangkan dengan menggunakan pengukuran NMAE nilai error berkisar dinilai 0,1000000 namun pada saat $\mathrm{K}$ dinaikan menjadi 40 dan 50 nilai error meningkat sebesar $0,03 \%$ dan $0,01 \%$, dan bila nilai $\mathrm{K}$ dinaikan mulai dari 60 ke 100 nilai error turun dan nilainya cenderung datar yaitu sebesar 0,114995936318163.

Performansi Item-Based Dengan Metode Pearson Terhadap Jumlah Neighborhood (Dataset Film)

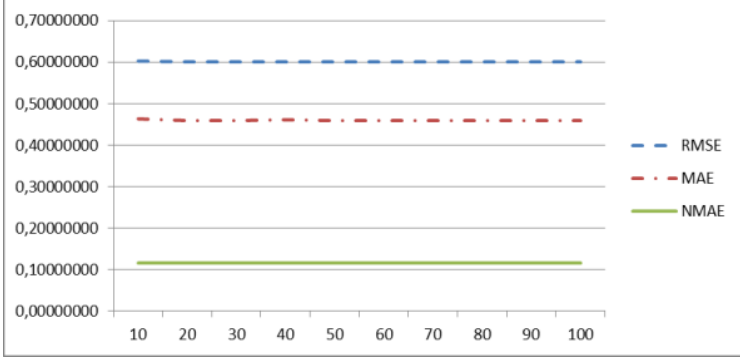

Gambar 3. 8 Performasi Item-Based Dengan Metode Pearson Correlation Terhadap Neighborhood

Pada Gambar 3.9 dapat dilihat bahwa pada userbased dengan menggunakan metode cosine similarity dengan pengukuran baik RMSE, MAE maupun NMAE jumlah neighborhood tidak mempengaruhi nilai error. Dengan pengukuran RSME nilai error untuk $\mathrm{K}=10$ sampai dengan $\mathrm{K}=100$ adalah sebesar 0,76841310544824, dengan pengukuran dengan menggunakan MAE nilai error untuk $\mathrm{K}=10$ sampai dengan $\mathrm{K}=100$ adalah sebesar 0,569602989188204, sedangkan dengan menggunakan pengukuran NMAE nilai error untuk $\mathrm{K}=10$ sampai dengan $\mathrm{K}=100$ adalah 0,142400747297051.

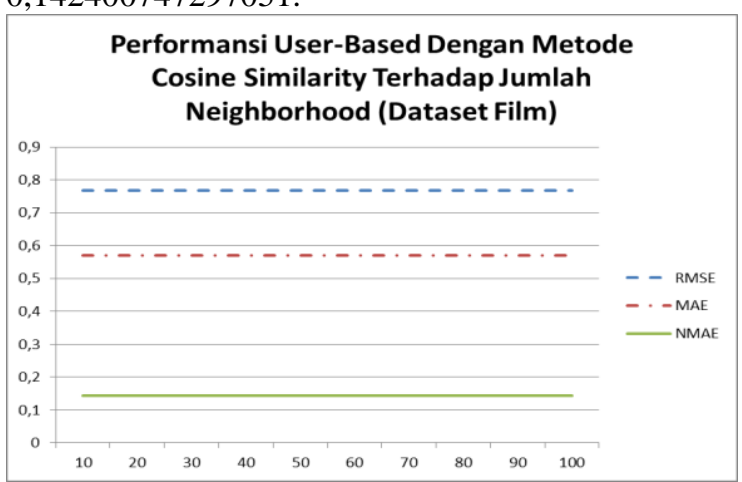

Gambar 3. 9 Performansi User-Based Dengan Metode Cosine Terhadap Neighborhood
Hal yang sama terjadi pada pengujian dengan user-based dengan menggunakan metode pearson correlation dimana pada saat diukur dengan menggunakan baik RMSE, MAE dan NMAE jumlah neighborhood tidak mempengahuri nilai error seperi yang terlihat pada Gambar 4.10. Dengan menggunakan pengukuran RMSE nilai error untuk $K=10$ sampai dengan $K=100$ cenderung datar yaitu sebesar 0,740916217363913, dan dengan menggunakan pengukuran MAE nilai error untuk $\mathrm{K}=10$ sampai dengan $\mathrm{K}=100$ adalah sebesar 0,554657422250493, sedangkan dengan menggunakan pengukuran NMAE nilai error untuk $\mathrm{K}=10$ sampai dengan $\mathrm{K}=100$ adalah sebesar 0,138664355562623 . Nilai error yang paling rendah adalah dengan menggunakan metode pengukuran NMAE, dan yang paling besar nilai errornya adalah dengan menggunakan metode pengukuran RMSE.

\section{Performansi User-Based Dengan Metode Pearson Terhadap Jumlah Neighborhood (Dataset Film)}

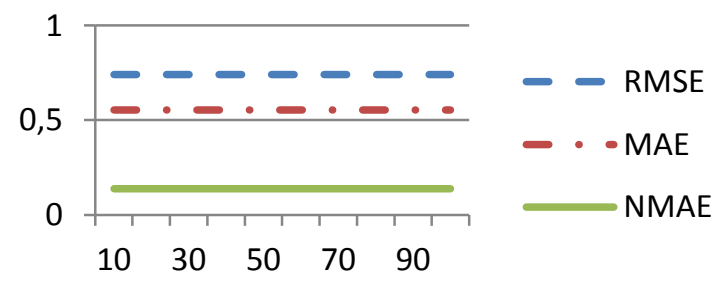

Gambar 3. 10 Performansi User-Based Dengan Metode Pearson Terhadap Neighborhood

Setelah dilakukan pengujian dengan dataset film selanjutnya adalah dilakukan pengujian dengan skenario yang sama dengan dataset buku, dengan menggunakan pengukuran RMSE nilai error tertinggi terjadi pada saat $\mathrm{K}=20$ dan nilai error terendah adalah pada saat $\mathrm{K}=60$ dan dari nilai $\mathrm{K}=10$ sampai dengan $\mathrm{K}=100$ nilai error rata-rata turun sebesar $2,05 \%$ seperti yang terlihat pada Gambar 4.11. Dengan menggunakan pengukuran MAE pada saat $\mathrm{K}$ dinaikan dari 10 ke 30 terjadi penurunan nilai error sebesar $6,4 \%$ kemudian pada saat $\mathrm{K}$ dinaikan menjadi 40 terjadi peningkatan error sebesar $3,3 \%$ sedangkan pada saat $K=50$ sampai dengan $\mathrm{K}=100$ nilai rata-rata penurunan nilai error sebesar 2,33\%. Sedangkan dengan pengukuran dengan menggunakan NMAE nilai error paling rendah pada saat $K=100$ yaitu sebesar 0,63418905780809 , dan nilai error tertinggi pada saat $\mathrm{K}=10$ yaitu sebesar 0,652045810497896 . 


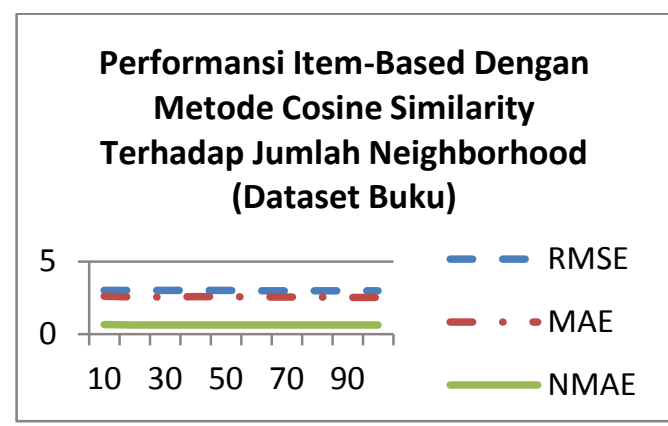

Gambar 3. 11 Performansi Item-Based Dengan Metode Cosine Terhadap Neighborhood

Hasil pengujian pada item-based dengan metode pearson correlation terlihat pada Gambar 3.12 dimana baik dengan menggunakan pengukuran RMSE, MAE, maupun NMAE jumlah neighborhood tidak mempengaruhi performansi dari metode yang diujikan dimana nilai error yang dimiliki pada saat $K=10$ sampai dengan $K=100$ adalah 2,82911171916649 bila diujikan dengan RMSE, dan bila diujikan dengan metode pengukuran MAE nilai error yang dimiliki aalah 2,46971747529278, sedangkan bila diujikan dengan menggunakan pengukuran NMAE nilai error adalah sebesar 0,617429368823195.

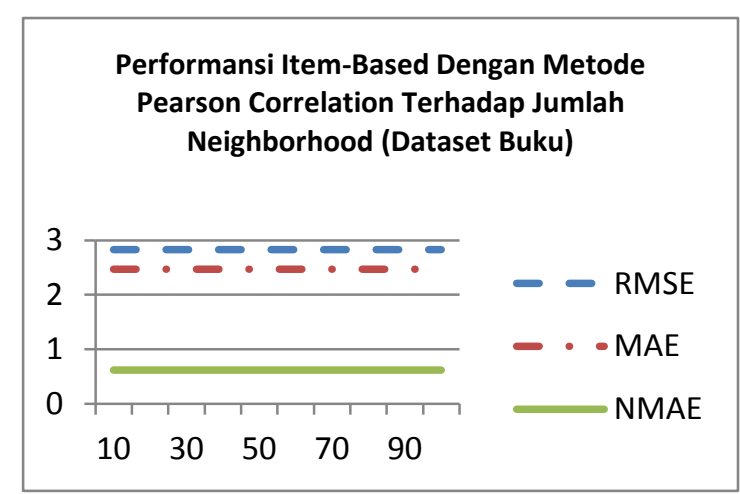

Gambar 3. 12 Performansi Item-Based Dengan Metode Pearson Terhadap Neighborhood

Pengujian dengan dataset buku dapat dilihat pada Gambar 3.13. Dengan menggunakan metode pengukuran RMSE, MAE dan NMAE pada userbased dengan menggunakan metode pengukuran cosine similarity tidak terpengaruhi oleh jumlah neighborhood, dengan nilai error tertinggi adalah pada saat diujikan dengan menggunakan pengukuran RMSE yaitu sebesar 2,86778109134839, dan bila diujikan dengan menggunakan pengukuran MAE nilai error yang dimiliki adalah sebesar 2,4923245948845 sedangkan bila diujikan dengan menggunakan NMAE nilai error yang dimiliki adalah sebesar 0,623081148721125 .

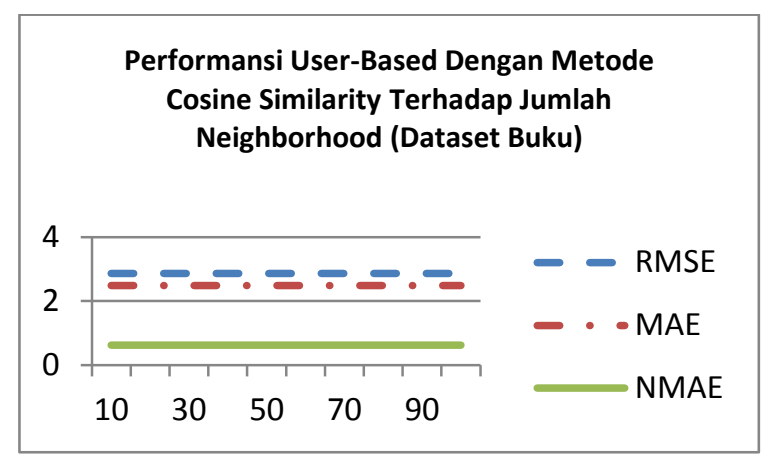

Gambar 3. 13 Performansi User-Based Dengan Metode Cosine Terhadap Neighborhood

Pada user-based dengan metode pearson correlation jumlah neighborhood juga tidak mempengaruhi performansi pada saat $\mathrm{K}=10$ sampai dengan nilai $\mathrm{K}=100$ nilai error terendah dimiliki pada saat dujikan dengan menggunakan NMAE dan nilai error tertinggi bila diujikan dengan menggunakan metode pengukuran RMSE. Nilai error yang diujikan dengan menggunakan pengukuran NMAE adalah sebesar 0,616879126153233, sedangkan bila diujikan dengan menggunakan pengukuran MAE adalah sebesar 2,46751650461293, dan bila diujikan dengan menggunakan RMSE nilai error yang dimiliki adalah sebesar 2,8258614876542 seperti yang terlihat pada Gambar 3.14.

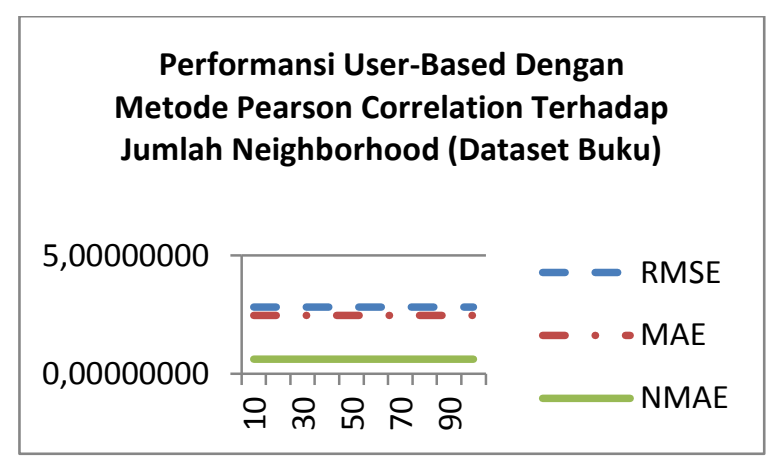

Gambar 3. 14 Performansi User-Based Dengan Metode Pearson Terhadap Neighborhood

\section{KESIMPULAN}

Penelitian ini membandingkan performa dari metode item-based dan user-based collaboratif filtering dengan menggunakan metode similaritas cosine similarity dan metode pearson correlation dengan menggunakan metode pengukuran RSME, MAE dan NMAE. Adapun dataset yang digunakan adalah dataset film dan dataset buku yang masing masing berjumlah 1659. Penelitian ini melakukan pengujian performa berdasarkan efek dari metode similarity yang digunakan dan 
berdasarkan efek dari jumlah neighborhood dengan $\mathrm{K}=10$ sampai dengan $\mathrm{K}=100$.

Berdasarkan hasil pengujian didapatkan hasil bahwa baik dengan dataset film maupun dengan dataset buku metode user-based dan item-based memiliki performa lebih baik bila menggunakan metode pearson correlation.

Sedangkan berdasarkan hasil pengujian terhadap efek dari ukuran neighborhood pada performansi metode item-based dan user-based dengan menggunakan dataset film dan diukur dengan menggunakan metode RMSE, MAE, dan NMAE didapatkan hasil sebagai berikut:

1. Performansi dari metode item-based dengan metode cosine similarity dengan dataset film dipengaruhi oleh ukuran neighborhood dimana pada saat jumlah neighborhood ditingkatkan dari 10 ke 30 nilai error meningkat sebesar $0,22 \%, 0,91 \%$, dan $0,22 \%$ diukur dengan menggunakan metode RMSE, MAE dan NMAE secara berurutan.

2. Performansi item-based dengan metode pearson correlation dengan dataset film juga dipengaruhi oleh jumlah neighborhood dimana pada saat jumlah neighborhood ditingkatkan menjadi 40 dan 50 terjadi peningkatan error sebesar $0,20 \%$ dan $0,22 \%$ untuk MAE dan $0,03 \%$ dan $0,01 \%$ untuk NMAE.

3. Pada user-based dengan menggunakan metode cosine similarity dengan pengukuran baik RMSE, MAE maupun NMAE jumlah neighborhood tidak mempengaruhi nilai error. Dimana pengukuran dengan RMSE didapatkan nilai error yang paling tinggi dibandingkan bila diujikan dengan MAE dan NME. Dengan pengukuran RSME nilai error untuk $\mathrm{K}=10$ sampai dengan $\mathrm{K}=100$ adalah sebesar 0,76841310544824, dengan pengukuran dengan menggunakan MAE nilai error untuk $K=10$ sampai dengan $K=100$ adalah sebesar 0,569602989188204, sedangkan dengan menggunakan pengukuran NMAE nilai error untuk $\mathrm{K}=10$ sampai dengan $\mathrm{K}=100$ adalah 0,142400747297051.

4. Performa dari user-based dengan pearson correlation berkualitas baik bila diukur dengan menggunakan NMAE dan jumlah neighborhood tidak mempengaruhi kualias prediksi baik diukur dengan menggunakan RMSE, MAE dan NMAE. Dengan menggunakan pengukuran RMSE nilai error untuk $K=10$ sampai dengan $K=100$ cenderung datar yaitu sebesar 0,740916217363913, dan dengan menggunakan pengukuran MAE nilai error untuk $K=10$ sampai dengan $K=100$ adalah sebesar 0,554657422250493, sedangkan dengan menggunakan pengukuran NMAE nilai error untuk $\mathrm{K}=10$ sampai dengan $\mathrm{K}=100$ adalah sebesar 0,138664355562623.

Dengan menggunakan dataset buku didapatkan hasil sebagai berikut:

1. Performansi dari item-based dengan metode cosine similarity dengan dataset buku dipengaruhi oleh jumlah neighborhood dimana dengan menggunakan pengukuran RMSE nilai error tertinggi terjadi pada saat jumlah neighborhood ditingkatkan ke 20 dan nilai error terendah adalah pada saat $K=60$ dan dari nilai $K=10$ sampai dengan $K=100$ nilai error rata-rata turun sebesar $2,05 \%$. Dengan menggunakan pengukuran MAE pada saat $\mathrm{K}$ dinaikan dari 10 ke 30 terjadi penurunan nilai error sebesar $6,4 \%$ kemudian pada saat $\mathrm{K}$ dinaikan menjadi 40 terjadi peningkatan error sebesar $3,3 \%$ sedangkan pada saat $K=50$ sampai dengan $K=100$ nilai rata-rata penurunan nilai error sebesar $2,33 \%$. Sedangkan dengan pengukuran dengan menggunakan NMAE nilai error paling rendah pada saat $\mathrm{K}=100$ yaitu sebesar 0,63418905780809, dan nilai error tertinggi pada saat $\mathrm{K}=10$ yaitu sebesar 0,652045810497896 .

2. Pada item-based dengan metode pearson correlation baik dengan menggunakan pengukuran RMSE, MAE, maupun NMAE jumlah neighborhood tidak mempengaruhi performansi dari metode yang diujikan.

3. Dengan menggunakan metode pengukuran RMSE, MAE dan NMAE pada user-based baik dengan menggunakan metode pengukuran cosine similarity maupun dengan menggunakan metode pearson correllation tidak dipengaruhi oleh jumlah neighborhood.

\section{DAFTAR PUSTAKA}

[1] Badrul Sarwar, George Karypis, Joseph Konstan, and John Riedl. Item-based collaborative filtering recommendation algorithms. In WWW '01: Proceedings of the 10th international conference on World Wide Web, pages 285295, New York, NY, USA, 2001. ACM..

[2] Carmegnola, F., Cena, F., Console, L., Cortassa O., Gena, C. Goy A., Torre I. (2008). Tag-based User Modeling for Social Multi-Device Adaptive Guides, Dipartimento Di Informatica, Torino

[3] Desrosiers, C., Karypis, G.. A Comprehensive Survey of Neighbourhood-based Recommendation Methods,2009,USA

[4] Greg Linden, Brent Smith, Jeremy York, Amazon.com Recommendations: Item-to-Item Collaborative Filtering, IEEE Internet Computing, v.7 n.1, p. 76-80, January 2003

[5] Herlocker, J., Konstan, J., Terveen, L., Borchers, A., Riedl, J..An Algorithmic Framework for Performing Collaborative Filtering, Berkeley, CA, 1999, USA

[6] J. Breese, D. Heckerman, and C. Kadie. Empirical analysis of predictive algorithms for collaborative ltering. In Proc. of Uncertainty in Articial Intelligence, 1998. 
IT FOR SOCIETY, Vol. 03, No. 01

ISSN 2503-2224

[7] Kwon, H., Lee, T., Hong, K. Improved Memory-based Collaborative Filtering using Entropy-based Similarity Measures, 2009, Hong Kong.

[8] Zan Huag, Daniel Zeng dan Hsinchun Chen, A Comparison of Collaborative-Filtering Recommendation Algorithms, 2007, IEEE Intelligent Systems.

[9] Movielens, https://movielens.org/.

[10] Grouplens.org. http://grouplens.org/

[11]Belka, T dan Plößnig, M. Designing recommender systems for tourism. Cairo. In Proceedings of ENTER. 2004.

[12] Toine Bogers, Antal Van den Bosch, Comparing and evaluating information retrieval algorithms for news recommendation, Proceedings of the 2007 ACM conference on Recommender systems, 2007.

[13]Baudisch, P. (1999). Joining collaborative and content based filtering, In: Interacting with Recommender Systems, Online Proceedings of the CHI '99 Workshop 